Article

\title{
Implementation of Fire Policies in Brazil: An Assessment of Fire Dynamics in Brazilian Savanna
}

\author{
Ananda Santa Rosa de Andrade ${ }^{1, *}\left(\mathbb{C}\right.$, Rossano Marchetti Ramos ${ }^{2}$, Edson Eyji Sano ${ }^{3}\left(\right.$, Renata Libonati ${ }^{4,5}$, \\ Filippe Lemos Maia Santos ${ }^{4,6}{ }^{(\mathbb{D}}$, Julia Abrantes Rodrigues $\left.{ }^{4}{ }^{(}\right)$, Marcos Giongo ${ }^{7}$, Rafael Rodrigues da Franca ${ }^{1}$ \\ and Ruth Elias de Paula Laranja ${ }^{1}$
}

check for updates

Citation: de Andrade, A.S.R.; Ramos, R.M.; Sano, E.E.; Libonati, R.; Santos, F.L.M.; Rodrigues, J.A.; Giongo, M.; da Franca, R.R.; de Paula Laranja, R.E. Implementation of Fire Policies in Brazil: An Assessment of Fire Dynamics in Brazilian Savanna. Sustainability 2021, 13, 11532. https:/ / doi.org/10.3390/su132011532

Academic Editor:

Raúl Romero-Calcerrada

Received: 9 August 2021

Accepted: 13 September 2021

Published: 19 October 2021

Publisher's Note: MDPI stays neutral with regard to jurisdictional claims in published maps and institutional affiliations.

Copyright: (c) 2021 by the authors. Licensee MDPI, Basel, Switzerland. This article is an open access article distributed under the terms and conditions of the Creative Commons Attribution (CC BY) license (https:// creativecommons.org/licenses/by/ $4.0 /)$.
1 Department of Geography, University of Brasilia, Brasília 70910-900, Brazil; rrfranca@unb.br (R.R.d.F.); laranja@unb.br (R.E.d.P.L.)

2 National Center for the Prevention and Fighting of Forest Fires, Brazilian Institute of the Environment and Renewable Natural Resources, Brasília 70818-900, Brazil; rossano.ramos@ibama.gov.br

3 Brazilian Agricultural Research Corporation, Planaltina 73301-970, Brazil; edson.sano@embrapa.br

4 Department of Meteorology, Federal University of Rio de Janeiro, Rio de Janeiro 21941-919, Brazil; renata.libonati@igeo.ufrj.br (R.L.); filmaias@hotmail.com (F.L.M.S.); abrant.julia@gmail.com (J.A.R.)

5 Center for Forestry Studies, Higher Institute of Agronomy, University of Lisbon, 1349-017 Lisbon, Portugal

6 Graduate Program in Climate and Environment (CLIAMB), National Institute for Research in the Amazon (INPA)/State University of Amazonas (UEA), Manaus 69069-001, Brazil

7 Center for Environmental Monitoring and Fire Management, Department of Forest Engineering, Federal University of Tocantins, Tocantins 77402-970, Brazil; giongo@uft.edu.br

* Correspondence: anandasrandrade@gmail.com

Abstract: In 2012, the Brazilian government implemented the Federal Brigades Program (FBP), a fire policy strategy to hire and train firefighters to combat wildfires. This study analyzed the impact of this program on fire behavior before (2008-2012) and after (2013-2017) its implementation in the Parque do Araguaia Indigenous Land, the largest indigenous territory with the highest occurrence of fires in the Brazilian tropical savanna. We analyzed the annual pattern of fire incidence in the dry season, the fire impact per vegetation type, the recurrence, and the relationship between fire and precipitation. The datasets were based on active fire products derived from the Moderate Resolution Imaging Spectroradiometer (MODIS), the Landsat and Resourcesat-based burned area products, and the records of the fire combat operations. Our results showed that FBP contributed to the reduction of the number of areas affected by fires and to the formation of a more heterogeneous environment composed of fire-resistant and fire-sensitive native vegetation fragments. On the other hand, after the implementation of the FBP, there was an increase in the recurrence of 3-4 years of fires. We concluded that the FBP is an important public policy capable of providing improvements in fire management activities.

Keywords: fire pattern; firefighters; indigenous land; environmental policy

\section{Introduction}

Wildfires disturb natural environments, affect socio-economic activities, and put the health and the life of people in danger [1]. More specifically, wildfires consume most of the surface organic layers and reduce stream water quality by increasing the inputs of soil erosional sediments and fertilizers [2]. Fires cause landscape fragmentation [3], loss of biodiversity [4], and release carbon stored in biomass and soils into the atmosphere, mostly in the form of $\mathrm{CO}_{2}$, but also as $\mathrm{CO}, \mathrm{CH}_{4}$, and $\mathrm{CH}_{3} \mathrm{Cl}$ [5-7]. Whenever the dry season is prolonged, fire severity and intensity can be aggravated due to the increase in the dry organic fuels that can cause extensive and uncontrolled wildfires [8-10]. Moritz and Stephens [11] recommended that future cities and rural communities should be created considering the low susceptibility to wildfires. 
In Brazil, fire in rural areas is mainly associated with illegal land cleaning for land speculation, land preparation for crop cultivation, pasture renewal, and charcoal production [12]. Fire prevention policy in Brazil is mainly based on field environmental law enforcement operations to combat and control illegal fire activities $[13,14]$. In addition, to reduce the negative consequences of fires and to comply with the goals established in international agreements, Brazil has regulated rules on the use of fire [15], created specific databases and public policies to support fire monitoring activities [16,17], and fostered projects based on technical cooperation agreements with other countries $[18,19]$. The work of the firefighters is also another important means to carry out fire prevention activities, environmental education, and combat wildfires [20,21]. The Federal Brigades Program (FBP) is part of the Sectorial Health Plan for the Mitigation and Adaption to Climate Change [22]. The objective of the FBP is to train and hire firefighters to reduce the extent and the number of fire occurrences during the dry season, combat wildfires, and carry out activities to prevent uncontrolled fires [23]. Brigades are hired whenever the Ministry of Environment (MMA) declares year-based emergency periods during the dry seasons in different regions of Brazil. The FBP operates continuously, with an average cost of $\sim 4.5 \times 10^{6}$ U.S. dollars in the period 2013-2017 since 2012 [23]. This is a rather low budget if compared with those from other countries, for example, $1.5 \times 10^{9}$ U.S. dollars in the period 2010-2020 in the United States [24] or $870 \times 10^{9}$ AU dollars in 2019/2020 in Australia [25].

Most of the scientific publications related to the rural fire brigades deal with safety, health, and psychological issues [26-28]. There are few studies investigating the effectiveness of rural fire brigades hired to reduce burned areas. An exception is a recent research study conducted by Oliveira et al. [29], which reported a reduction of $12 \%$, on average, of burned areas in conservation units located in the Brazilian Cerrado (tropical savanna) with brigades, compared with those units without brigades. The same study found a reduction of an additional 6\% of burned areas in the Cerrado's conservation units with both fire suppression and prevention activities in comparison with those units with only suppression practices.

After decades of frustrating attempts of implementing zero-fire policies, Brazil started to implement fire management policies, reintroducing fire as a management tool in fireprone ecosystems, which is the case of the Brazilian Cerrado [30,31]. Firefighters hired by the FBP are important players of these policies. They can act not only in federal conservation units of integral protection or sustainable use but also in indigenous lands, public forests, federal rural settlements, and quilombos. The research question of this study is: how effective is the FBP in reducing the size, number, and recurrence of fires in the Brazilian Cerrado? To our best knowledge, there is a lack of studies regarding the effectiveness of the FBP-based actions to prevent wildfires in Brazil. To evaluate these possible effects of FBP, this study aimed to compare the spatial variability of fires before (2008-2012) and during (2013-2017) the implementation of the FBP in the Parque do Araguaia Indigenous Land.

\section{Materials and Methods}

\subsection{Study Area}

The study area corresponds to the Parque do Araguaia Indigenous Land (Figure 1), with an approximate surface area of $13 \times 10^{3} \mathrm{~km}^{2}$. This territory corresponds to a large seasonal wetland and the intracratonic Quaternary sedimentary basin of South America, flooded mainly by rainfall and groundwater [32,33]. The annual flooding occurs during the rainy season mainly from the Javaés and Araguaia rivers [32]. The region is a mosaic of phytophysiognomies that are either resistant to fire (shrublands and wooded grasslands) or sensitive to fire (forestlands) [34]. The climate is tropical, has an average annual rainfall ranging from $1200 \mathrm{~mm}$ to $1800 \mathrm{~mm}$ [34], and an average temperature ranging from $22{ }^{\circ} \mathrm{C}$ to $26^{\circ} \mathrm{C}$ [35]. The dry season occurs between May and October, while the rainy season occurs between October and April. 


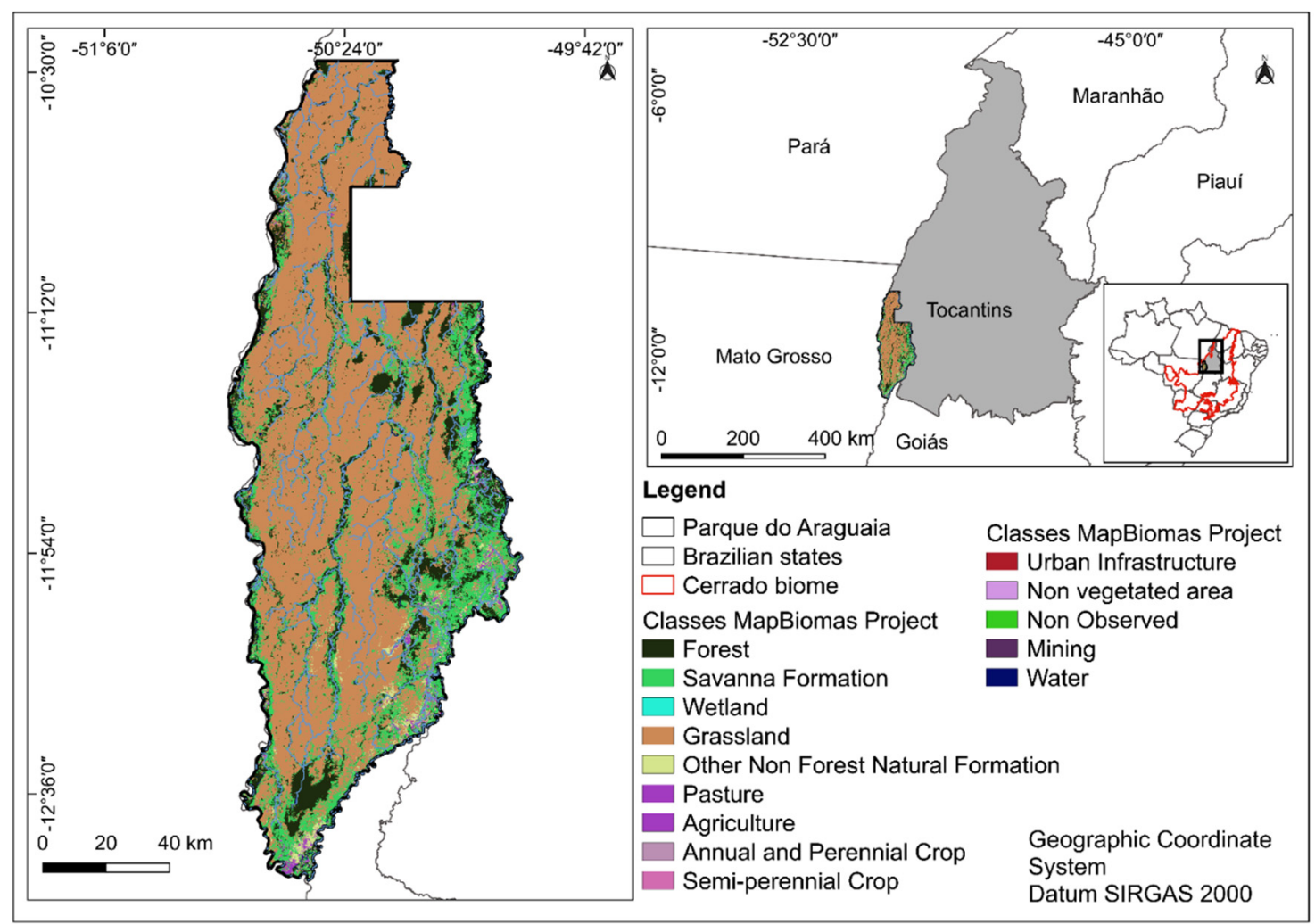

Figure 1. Location of the Parque do Araguaia Indigenous Land in the Tocantins State and in the Cerrado biome and the main land cover classes according to MapBiomas. Source: Ramsar [36].

Fires in indigenous lands are related to traditional cultivation methods [37] or illegally set by hunters and land grabbers [38]. Since 2013, the Parque do Araguaia Indigenous Land is one of the IBAMA's highest priority areas to mitigate degradation caused by wildfires, with 217 contracts awarded between 2013 and 2017. Most of the hired firefighters were indigenous people residing in this Park (Table 1).

Table 1. Total number of firefighters hired by the Federal Brigade Program in the Parque do Araguaia Indigenous Land in the period 2013-2017.

\begin{tabular}{cc}
\hline Year & Number of Hired Firefighters \\
\hline 2013 & 15 \\
2014 & 44 \\
2015 & 58 \\
2016 & 50 \\
2017 & 50 \\
\hline Total & 217 \\
\hline
\end{tabular}

\subsection{Datasets}

We selected the Moderate Resolution Imaging Spectroradiometer (MODIS) Active Fire product (MCD14ML), collection 6, which is derived applying thresholds to the brightness temperatures from the middle-infrared and thermal infrared spectral bands of the MODIS sensor onboard the Aqua and Terra platforms (https: / firms.modaps.eosdis.nasa.gov/ download/, accessed on 30 June 2020). We considered the data obtained from 2008 to 2017 and made available by the Fire Information for Resource Management System [39,40]. Active fires are identified when the fire reaches a pixel fraction equal to or greater than $0.01 \%\left(100 \mathrm{~m}^{2}\right)$ and an average brightness temperature of $800 \mathrm{~K}$. 
We also used the burned area product obtained from the Center for Environmental Monitoring and Fire Management, Federal University of Tocantins, which corresponds to the surface affected by fire in the dry season (accessible upon request). The detection of the burned area was with the visual interpretation of the burn scars in two annual images obtained by the Landsat 5 and Landsat 8 satellites (spatial resolutions of $30 \mathrm{~m}$ ) and from the Resourcesat satellite (spatial resolution of $23.5 \mathrm{~m}$ which were resampled to $30 \mathrm{~m}$ ) [41]. Before the analyses, we revised and recalculated the burned areas for the period 2008-2017 considering surfaces equal or larger than $9 \times 10^{-4} \mathrm{~km}^{2}$ (same area as a Landsat pixel).

The annual land use and land cover (LULC) maps from the MapBiomas Project [42], collection 4.1, from 2008 to 2017 (https:/ / mapbiomas.org/en/colecoes-mapbiomas-1? cama_set_language=en, accessed on 12 May 2020), were used to assess the association between fire and type of vegetation affected. These maps are made available at the 30-m spatial resolution. The vegetation types classified by this Project were grouped as fire-sensitive vegetation (forest formations) or fire-resistant vegetation (savanna and grassland formations).

Daily rainfall data from 1 January 2008 to 31 December 2017 were obtained from NASA's Goddard Earth Sciences Data and Information Services Center (3B42 product, version 7), with a spatial resolution of $0.25^{\circ} \times 0.25^{\circ}$ (https:/ /gpm.nasa.gov/data/directory, accessed on 21 October 2019). This product is the largest global hydrometeorological database in the world [43]. The 3B42 product combines data from weather stations and GOES-E, GOES-W, Meteosat-5, Meteosat-7, NOAA-12, and Tropical Rainfall Measuring Mission (TRMM) satellite data. Validation studies of these daily rainfall data conducted by [44] yielded satisfactory results for the northern Brazilian region, the region context of the Parque do Araguaia Indigenous Land.

Records of fire combat operations between 2014 and 2017 were also selected from the Integrated Multi-Agency Center for Operational Coordination (Ciman Virtual) (http:/ / queimadas.dgi.inpe.br/queimadas / ciman, accessed on 12 December 2019). This platform was created in 2014 by the National Institute for Space Research (INPE) to make the information obtained by the wildfire operations (costs, number of firefighters, and dates of operation) publicly available [45].

\subsection{Analysis}

Figure 2 shows the flowchart with the main analyzes conducted in this study. The spatial and temporal distribution of rainfall and fire in the study area were analyzed based on maximum values and standard deviation of the burned areas, the number of fire scars, mean monthly rainfall values, duration of the annual dry periods (in days), and the number of dry days before (2008-2012) and during (2013-2017) the creation of FBP, hereafter named BFBP and DFBP, respectively. We considered dry days as with daily precipitation values less than $3 \mathrm{~mm}$ of rain and the annual dry season as the largest period of consecutive dry days per year. All burned areas forming distinct polygons were considered different fire scars, regardless of their size or proximity with each other.

Finally, the effects of the dry days and the rainfall (both restricted for the fire season, May to October) on the total burned area and fire cells were analyzed through the Spearman correlations, considering a significance ( $p$-value) less than $0.05(p<0.05)$.

The spatial distribution of the accumulated number of active fires was analyzed stratifying the study area in a regular grid of $1 \times 1 \mathrm{~km}$. The active fires data were intersected with the grid. A grid cell with at least one active fire was classified as a "fire cell" regardless of the number of detections within the cell. The other cells were discarded. The total number of annual fire cells during the dry season (May to October) were accumulated monthly and analyzed considering before and during the establishment of FBP. 


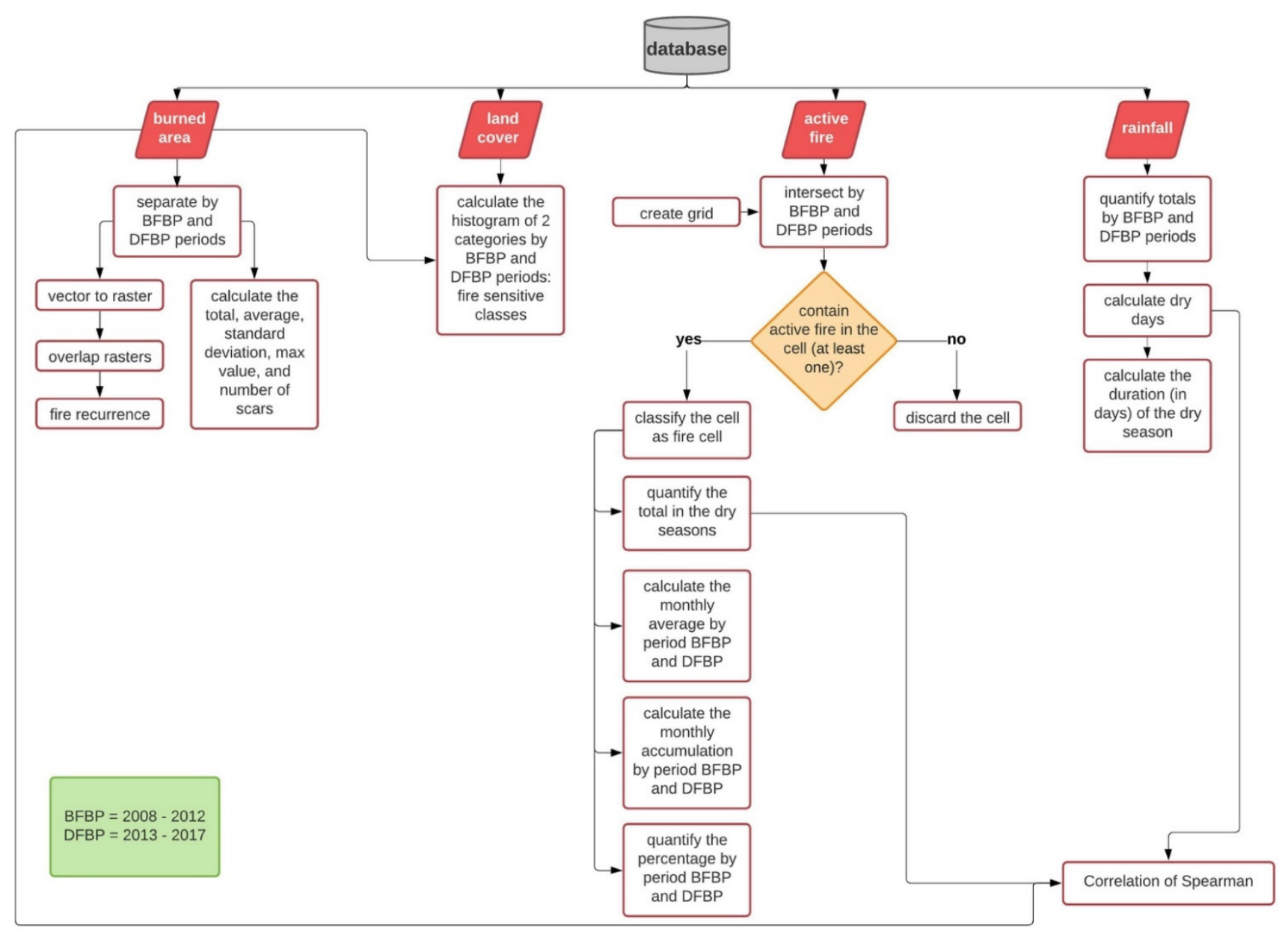

Figure 2. Flowchart of the analyses. BFBP = before Fire Brigades Program; DFBP = during Fire Brigades Program.

The relationship between fire and the type of vegetation present in the Parque do Araguaia Indigenous Land was investigated based on the annual percentage of classes and pixel counts before and during the FBP. Then, an analysis was made on an annual basis of vegetation that was impacted by fire relative to the total vegetation resistant to fire (savanna and grass formations) and sensitive to fire (forests).

We calculated the fire recurrence by overlapping the annual totals of burned areas for the BFBP and DFBP periods. Here, the vector-based, annual burned area data were converted into raster format and pixel values were classified in binary values of either 0 (pixels with no burned area) or 1 (pixels with the burned area). We then counted the number of times that a specific pixel presented class 1 before FBP and during FBP. A pixel having class 1 for two times was considered as having one-year recurrence; three times, two-year recurrence; four-times, three-year recurrence; and five-time, four-year recurrence. We also categorized the results according to the type of vegetation impacted (fire-resistant and fire-sensitive).

\section{Results and Discussion}

\subsection{The Spatial Distribution of Fires in the Parque do Araguaia Indigenous Land}

Active fires were found in all months of the BFBP and DFBP periods, except in March, after the implementation of FBP (Figure 3). The highest occurrences were between June and October. The peaks occurred in August (BFBP) and September (BFBP and DFBP), after three months without significant rainfall (Figure 4). In these months, we find traditional fields burned by the indigenous people, along with the activities of the brigades. With the 
beginning of the rainy season in October, the number of areas affected by fire gradually reduced until May of the following year.

The fire and rainfall patterns were quite similar before and during the FBP. However, the monthly sums of cells with fires BFBP in May, June, and July were slightly lower (16.1\%) than those from DFBP (16.4\%). During the peak of the dry season (August and September) and during the transition between dry and wet seasons (October), there was a reduction in the number of cells for the BFBP $(83.4 \%)$ and DFBP $(80.0 \%)$ periods. This change in the fire pattern during the FBP is a result of prevention activities conducted by firefighters by using controlled fires and black firebreak [46] and the implementation of Integrated Fire Management in 2015, including prescribed burning at the end of the rainy season and beginning of the dry season $[47,48]$. Even though the values are not significant, the difference in the patterns between the middle and the end of the dry season during the FBP can be seen as a positive result of the preventive activities of the program.

The smallest and largest burned areas were found in $2009\left(1152 \mathrm{~km}^{2}\right)$ and 2010 $\left(11,057 \mathrm{~km}^{2}\right)$ (Table 2), respectively, therefore, BFBP. The lowest number and the highest average size of fire scars were found in 2010. The second-largest burned areas (third in the entire historical series of this study) were found in 2008 (BFBP), while 2011 had the second-lowest value recorded in the period 2008-2017. During the FBP, the lowest total burned area (third lowest value for the entire historical series) was found in 2013, and the highest value (second highest in the historical series) in 2017.

The high values of burned areas in 2010 were influenced by the extreme drought and the duration of the dry season caused by the El Niño climate phenomenon and the warming of the Tropical North Atlantic Ocean current [49-51]. In 2017, there was no extreme climate event, although rainfall was below average in the Cerrado biome from May to October [52] and with the longest drought duration (the longest in the DFBP period). These two events in 2010 and 2017 aid in understanding the impact of rainfall on the size of the burned areas, as pointed out by Mistry [53], Govender et al. [54], and Daldegan et al. [10]. This relationship was also evident in the study area according to the results of Spearman's correlations which had significant, strong, and positive relations between burned areas and dry days burned areas, and rainfall, burned areas and fire cells (Table 3).

The results in Table 2 also refer to an interpretation of landscape fragmentation caused by fire, due to the high standard deviation of the burned area values and the number of fire scars, which do not present a defined pattern before and during the FBP. As the incidence of fire occurs practically every month of the year in the indigenous land (Figure 3), the intra-annual variability of the burned areas can be explained by the quality and quantity of the fuel (biomass) [55].

The longer the time without rainfall, the temperature elevates, and the relative air humidity reduces. This relation affects the flammability of organic fuel and, consequently, the susceptibility to wildfires [56]. Thus, the increase in the extent of the burned areas with an accumulation of organic fuel is facilitated, as this factor also favors the magnitude and spread of the fire at the end of the dry season [57-59]. In this way, the largest extensions of burned areas are more commonly found at the end of the dry season, while smaller ones are more commonly found during the rainy season and at the beginning of the dry season [60].

The average values of fire scars and the maximum values of burned areas were higher, and then lower, respectively, during the FBP, allowing the formation of mosaics from areas with and without fire. This pattern provides a greater environmental heterogeneity, facilitating the regeneration of burned vegetation and avoiding more severe fires at the end of the dry season $[61,62]$. Despite these positive responses, it is important to condition them to the analysis of the frequency of fire and impacted vegetation. 


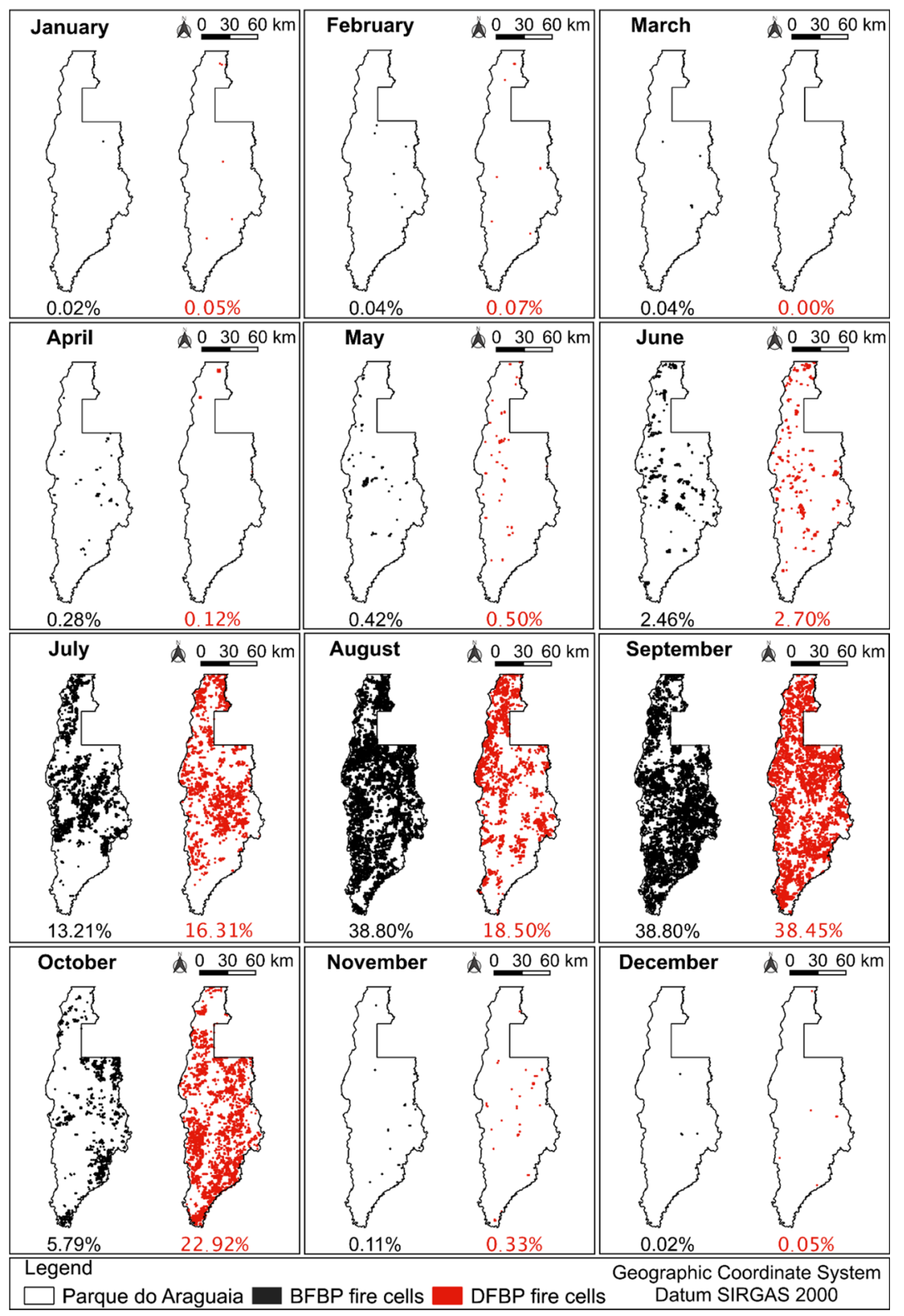

Figure 3. Monthly accumulation percentage of fire cells in the Parque do Araguaia Indigenous Land before (2008-2012; black), and during the Federal Brigades Program (2013-2017; red) periods. $\mathrm{BFBP}=$ before the Federal Brigades Program; DFBP = during the Federal Brigades Program. 


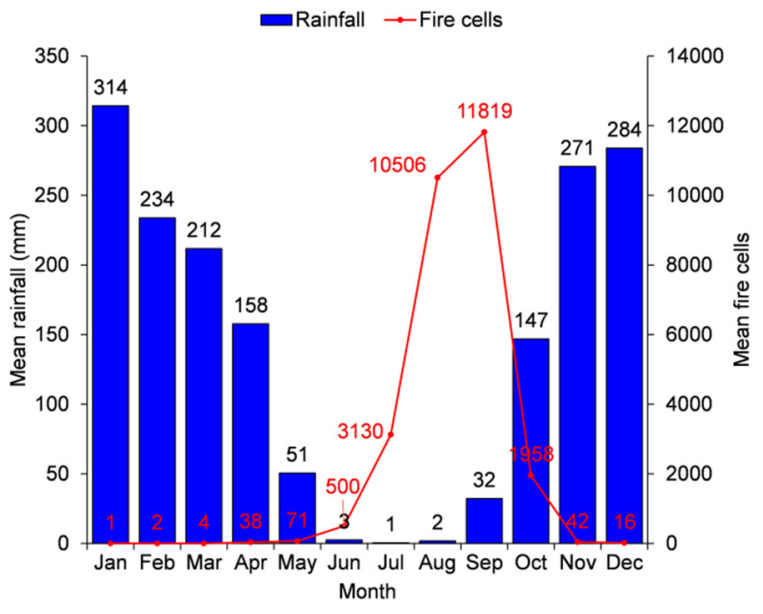

(a)

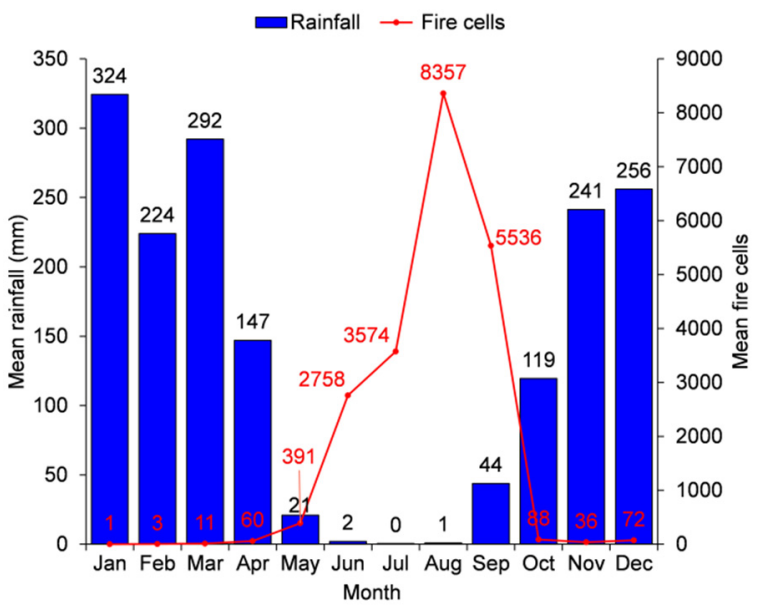

(b)

Figure 4. Average monthly rainfall and number of fire cells before the Federal Brigades Program (a) and during the Federal Brigades Program (b).

Table 2. Annual description of the burned areas and rainfall in the Parque do Araguaia Indigenous Land, before and during the Federal Brigades Program. BFBP = before the Federal Brigades Program; DFBP = during the Federal Brigades Program.

\begin{tabular}{|c|c|c|c|c|c|c|c|c|}
\hline Period & Year & $\begin{array}{c}\text { Total } \\
\text { Burned } \\
\text { Area }\left(\mathbf{k m}^{2}\right)\end{array}$ & $\begin{array}{c}\text { Standard } \\
\text { Deviation } \\
\left(\mathbf{k m}^{2}\right)\end{array}$ & $\begin{array}{c}\text { Average } \\
\text { Burned } \\
\text { Area }\left(\mathbf{k m}^{2}\right)\end{array}$ & $\begin{array}{c}\text { Maximum } \\
\text { Burned Area } \\
\left(\mathbf{k m}^{2}\right)\end{array}$ & $\begin{array}{c}\text { Total } \\
\text { Number of } \\
\text { Fire Scars }\end{array}$ & $\begin{array}{c}\text { Total } \\
\text { Rainfall } \\
(\mathrm{mm})\end{array}$ & $\begin{array}{c}\text { Duration of } \\
\text { the Dry } \\
\text { Season (days) }\end{array}$ \\
\hline \multirow{6}{*}{ BFBP } & 2008 & 7273 & 321 & 66 & 2508 & 111 & 1837 & 147 \\
\hline & 2009 & 1152 & 16 & 7 & 135 & 172 & 1867 & 118 \\
\hline & 2010 & 11,058 & 1843 & 325 & 10,754 & 34 & 1512 & 170 \\
\hline & 2011 & 1193 & 40 & 9 & 299 & 128 & 1916 & 163 \\
\hline & 2012 & 4072 & 161 & 18 & 2408 & 226 & 1404 & 109 \\
\hline & Mean & 4949 & 476 & 85 & 3221 & 134 & 1707 & 141 \\
\hline \multirow{6}{*}{ DFBP } & 2013 & 2819 & 100 & 27 & 744 & 106 & 1891 & 95 \\
\hline & 2014 & 3579 & 88 & 15 & 1116 & 236 & 1788 & 98 \\
\hline & 2015 & 5244 & 167 & 46 & 1220 & 113 & 1404 & 124 \\
\hline & 2016 & 5978 & 273 & 39 & 3262 & 155 & 1498 & 139 \\
\hline & 2017 & 8349 & 332 & 41 & 4242 & 204 & 1780 & 152 \\
\hline & Mean & 5194 & 192 & 34 & 1897 & 163 & 1672 & 122 \\
\hline
\end{tabular}

Table 3. Spearman correlation results for the whole series (2008-2017) from May to October. Significant values at $p<0.05$ are depicted in bold.

\begin{tabular}{ccc}
\hline Spearman Correlation & Dry Days & Rainfall \\
\hline Burned areas & $\mathbf{0 . 8 1}$ & $\mathbf{- 0 . 8 6}$ \\
Fire cell & 0.50 & $\mathbf{0 . 7 9}$ \\
\hline
\end{tabular}

\subsection{Fire Frequency, Areas Affected by Fire, and the Occurrence of Large Forest Fires}

The total areas without overlapped burned areas (without incidence of fire and incidence of up to one year) were high in both periods, although, for the other types of fire recurrence, there was a difference between before and during FBP. During FBP, there were a smaller number of areas with one and two years of fire frequency ( $41 \%$ and $11 \%$ less during the FBP, respectively). In contrast, areas without fire recurrence and with inter-annual fire recurrence of three and four years were higher during the $\mathrm{FBP}(16 \%, 180 \%$, and $751 \%$ more before the FBP, respectively) (Table 4). The increase in areas with three and four years of 
fire recurrence during the FBP period was high in the natural vegetation, especially in the northern, northeastern, and southeastern portions of the indigenous land (Figure 5).

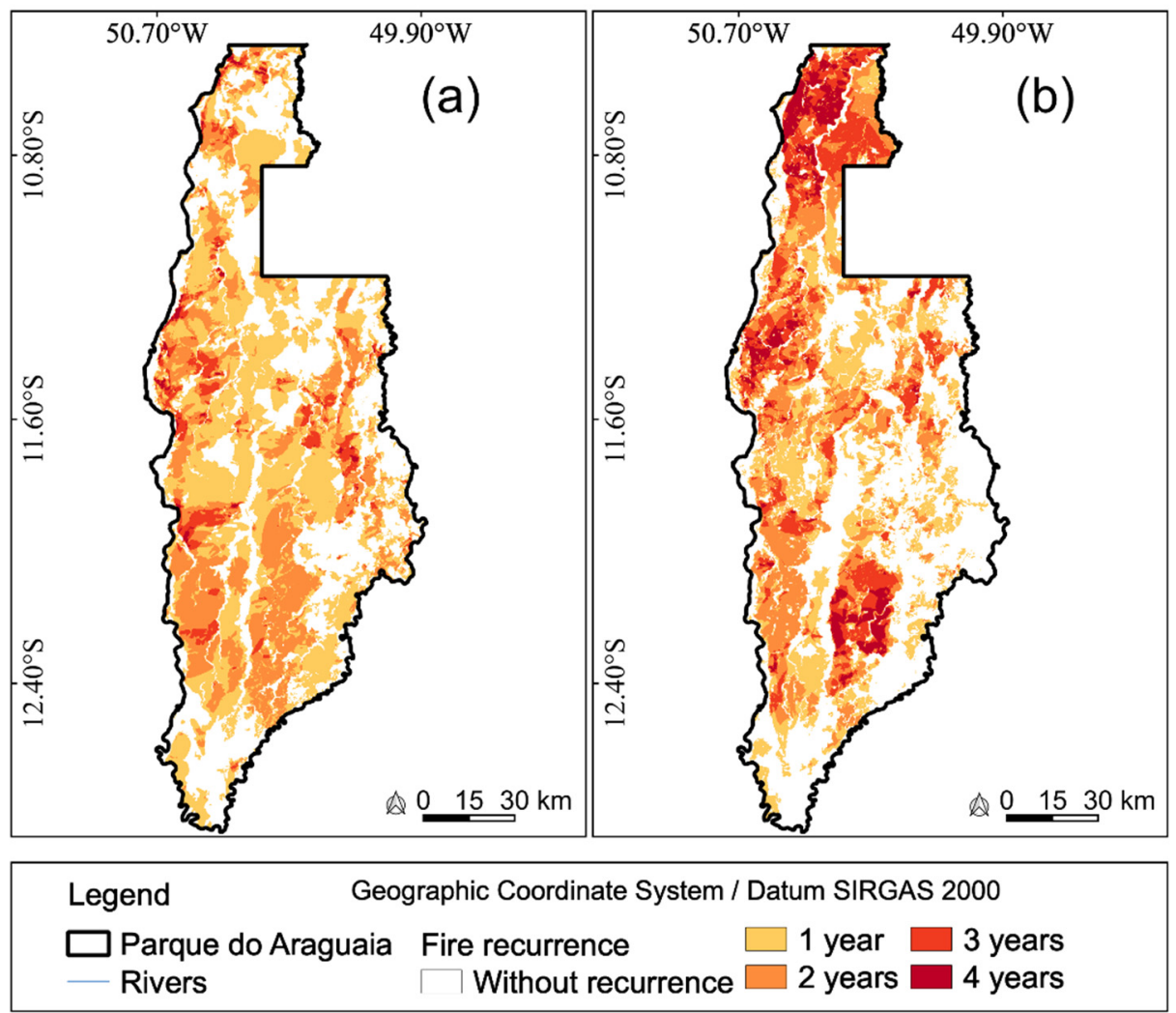

Figure 5. Recurrence of burned areas before the Federal Brigades Program (a) and during the Federal Brigades Program (b).

Table 4. Recurrence of burned areas in the Parque do Araguaia Indigenous Land. The differences were calculated using the data for total area of recurrence and area of vegetation types before and during FBP. BFBP = before the Federal Brigades Program; DFBP = during the Federal Brigades Program. Dif. = difference.

\begin{tabular}{|c|c|c|c|c|c|c|c|c|c|}
\hline \multirow{3}{*}{ Recurrence } & \multicolumn{4}{|c|}{ Burned Area } & \multicolumn{5}{|c|}{$\begin{array}{c}\text { Affected Vegetation in Relation to the Fire } \\
\text { Recurrence }\end{array}$} \\
\hline & \multirow[b]{2}{*}{$\begin{array}{l}\text { BFBP } \\
\left(\mathrm{km}^{2}\right)\end{array}$} & \multirow[b]{2}{*}{$\begin{array}{l}\text { DFBP } \\
\left(\mathbf{k m}^{2}\right)\end{array}$} & \multirow[b]{2}{*}{ Dif. (\%) } & \multirow[b]{2}{*}{$\begin{array}{l}\text { Sensitive } \\
\left(\mathbf{k m}^{2}\right)\end{array}$} & BFBP & \multicolumn{3}{|c|}{ DFBP } & \multirow{2}{*}{$\begin{array}{c}\text { \% Dif. } \\
\begin{array}{c}\text { Fire- } \\
\text { Resistant }\end{array}\end{array}$} \\
\hline & & & & & $\begin{array}{c}\text { Fire- } \\
\text { Resistant }\left(\mathbf{k m}^{2}\right)\end{array}$ & $\begin{array}{l}\text { Sensitive } \\
\left(\mathbf{k m}^{2}\right)\end{array}$ & $\begin{array}{l}\text { Fire-Resistant } \\
\quad\left(\mathrm{km}^{2}\right)\end{array}$ & Sensitive & \\
\hline No. & 5094 & 5903 & 16 & 4838 & 9534 & 1998 & 3435 & -142 & -178 \\
\hline 1 year & 5133 & 3024 & -41 & 295 & 4788 & 125 & 2839 & -137 & -69 \\
\hline 2 years & 3076 & 2733 & -11 & 66 & 3005 & 35 & 2673 & -92 & -12 \\
\hline 3 years & 588 & 1645 & 180 & 9 & 579 & 9 & 1622 & 2 & 64 \\
\hline 4 years & 78 & 664 & 751 & 0 & 78 & 9 & 643 & 95 & 88 \\
\hline
\end{tabular}

This recurrence response is related to the annual incidence of fires. Throughout the series (2008-2017), both sensitive vegetation and fire-resistant vegetation were affected by fire (Table 5). The year in which fire-sensitive and fire-resistant vegetation burned the most was in 2010 (before the FBP). With the implementation of the FBP, the mean area of vegetation affected by the fire was smaller in this period, but with progressive growth of affected areas since 2013. 
Table 5. Percentage of areas affected by the fire and by classes from the MapBiomas Project compared with the total area of each class in the Parque do Araguaia Indigenous Land. BFBP = before the Federal Brigades Program; DFBP = during the Federal Brigades Program.

\begin{tabular}{|c|c|c|c|}
\hline Period & Year & $\begin{array}{c}\text { Fire-Sensitive } \\
\text { Vegetation (\%) }\end{array}$ & $\begin{array}{c}\text { Fire-Resistant } \\
\text { Vegetation (\%) }\end{array}$ \\
\hline \multirow{5}{*}{ BFBP } & 2008 & 18.0 & 62.1 \\
\hline & 2009 & 1.4 & 10.1 \\
\hline & 2010 & 41.6 & 89.9 \\
\hline & 2011 & 2.7 & 10.2 \\
\hline & 2012 & 7.9 & 35.5 \\
\hline \multicolumn{2}{|c|}{ Mean } & 14.3 & 41.6 \\
\hline \multirow{5}{*}{ DFBP } & 2013 & 2.1 & 24.5 \\
\hline & 2014 & 4.1 & 31.0 \\
\hline & 2015 & 5.0 & 45.9 \\
\hline & 2016 & 8.3 & 52.0 \\
\hline & 2017 & 13.0 & 72.5 \\
\hline \multicolumn{2}{|c|}{ Mean } & 6.5 & 45.2 \\
\hline
\end{tabular}

The ecological importance of fire in the Cerrado is well-known in the literature [63,64]; nevertheless, the impacts and responses are different in each type of phytophysiognomy found in the biome. Cerrado stricto sensu (grasslands and shrublands) are resistant to fire due to morphology [65] — thick bark, protection of subterranean gems and organs-and plant physiology [66] — translocation of nutrients for underground tissues at the beginning of the drought.

To have a resilient relationship between fire and pyrophytic vegetation, a period of recovery from fire is necessary since each fire overlapping in the same area can increase the damage and mortality of shrub and tree strata, change the plant physiognomy, and delay the passage of specimens to the reproductive stage $[67,68]$.

The need for a fire interval of two or three years to allow regrowth of fire-resistant phytophysiognomies, in some cases, up to four years, is already known [69]. Despite the need for studies to understand the appropriate period of fire recurrence in the ecosystems that exist in the Parque do Araguaia Indigenous Land, with the creation of FBP, the opposite was observed: increase in 3-4-year recurrences and decrease in 1-2-year recurrence.

For fire-sensitive ecosystems, the burned area detection and their recurrence are problematic. In forested areas, there is no positive relationship with the direct incidence of fire, regardless of the period and frequency of occurrence. Forest trees are sensitive to fire [70], and they do not exhibit morphological or physiological characteristics of tree species that occur in the Cerrado stricto sensu. Thus, when there is fire, whether preventive or illegal, there is the possibility of severe impacts on the floristic composition, structure, and survival of individuals [71]. The growth of areas without fire recurrence and with up to one year of burning in an interval of five years during the FBP also indicates another problem-the accumulation of dry organic fuel. This fact provides several impacts, including the homogenization of the landscape, the exclusion of lightdependent herbaceous species, and wildfires [71-73]. Three large wildfires occurred in the indigenous land during the FBP $(2014,2016$, and 2017), requesting relatively large costs to the Brazilian public budget. According to data from the Ciman Virtual platform, these fires may have been the result of an accumulation of dry organic fuel.

The environmental impacts of the large wildfires and the high recurrence fires have a great impact on the daily life of traditional peoples as well as on the unique biodiversity of the Parque do Araguaia Indigenous Land. Degradation may also reflect the loss of forested areas (data analysis revealed a $2 \%$ reduction in forested areas during the FBP). There is a risk of the continuation of fire degradation as well as the decline of fire-sensitive phytophysiognomies found in the indigenous land if there are no changes in the Program to reduce these detected adversities. 


\section{Conclusions}

The FBP is undoubtedly important in the Brazilian environmental policy to reduce wildfires in the Cerrado biome, based on the training and qualification of firefighters to work in protected areas and, whenever necessary, in other areas-federal or state. In the Parque do Araguaia Indigenous Land, the FBP was able to reduce the number of areas affected by the fire at the end of the dry season and helped to create a mosaic of fragments of native vegetation without fire and fire-affected fragments. Negatively, during the execution of the Program in the indigenous land, the number of areas with an accumulation of organic fuel increased and the recurrence of 4-5-year fire also increased.

To mitigate the unfavorable results of the FBP evidenced in this research, it is necessary to incorporate scientific assessments on the impacts of fire on flora and fauna, as well as mapping areas with high recurrence of fire and accumulation of organic fuel before and during the fire prevention and combat activities. Furthermore, monitoring meteorological conditions throughout the year is needed to formulate emergency plans whenever adverse climatic events are identified. In this context, the FBP promotes an opportunity to engage in further discussions with the goal of maintaining and improving the conservation of the savanna ecosystem.

Author Contributions: Conceptualization, methodology, project administration, and writingoriginal draft preparation, A.S.R.d.A.; conceptualization and writing—review and editing, R.M.R.; supervision, data curation and writing - review and editing, E.E.S., R.L., F.L.M.S., J.A.R. and M.G.; review, R.E.d.P.L. and R.R.d.F. All authors have read and agreed to the published version of the manuscript.

Funding: This research was supported by the Graduate Program in Geography at the University of Brasília, by the Brazilian Coordination for the Improvement of Higher Education Personnel (CAPES) (Financing code 001), and by the Brazilian National Council for Scientific and Technological Development (CNPq).

Institutional Review Board Statement: Not applicable.

Informed Consent Statement: Not applicable.

Data Availability Statement: All data are public available.

Acknowledgments: The authors are grateful for the valuable comments from two anonymous reviewers.

Conflicts of Interest: The authors declare no conflict of interest.

\section{References}

1. Viegas, D.X.; Ribeiro, L.M.; Viegas, M.T.; Pita, L.P.; Rossa, C. Impacts of fire on society: Extreme fire propagation issues. In Earth Observation of Wildland Fires in Mediterranean Ecosystems; Chuvieco, E., Ed.; Springer: Berlin, Germany, 2019; pp. 97-109.

2. Rhoades, C.C.; Chow, A.T.; Covino, T.P.; Fegel, T.S.; Pierson, D.N.; Rhea, A.E. The legacy of a severe wildfire on stream nitrogen and carbon in headwater catchments. Ecosystems 2019, 22, 643-657. [CrossRef]

3. Alencar, A.A.; Brando, P.M.; Asner, G.P.; Putz, F.E. Landscape fragmentation, severe drought, and the new Amazon forest fire regime. Ecol. Appl. 2015, 25, 1493-1505. [CrossRef] [PubMed]

4. Silveira, J.M.; Louzada, J.; Barlow, J.; Andrade, R.; Mestre, L.; Solar, R.; Lacau, S.; Cochrane, M.A. A multi-taxa assessment of biodiversity change after single and recurrent wildfires in a Brazilian Amazon Forest. Biotropica 2016, 48, 170-180. [CrossRef]

5. Alden, C.B.; Miller, J.B.; Gatti, L.V.; Gloor, M.M.; Guan, K.; Michalak, A.M.; van der Laan-Luijkx, I.T.; Touma, D.; Andrews, A.; Basso, L.S.; et al. Regional atmospheric $\mathrm{CO}_{2}$ inversion reveals seasonal and geographic differences in Amazon net biome exchange. Glob. Chang. Biol. 2016, 22, 3427-3443. [CrossRef] [PubMed]

6. Aragão, L.E.; Anderson, L.O.; Fonseca, M.G.; Rosan, T.M.; Vedovato, L.B.; Wagner, F.H.; Silva, C.V.; Silva Júnior, C.H.; Arai, E.; Aguiar, A.P. 21st century drought-related fires counteract the decline of Amazon deforestation carbon emissions. Nat. Commun. 2018, 9, 536. [CrossRef]

7. Wei, X.; Hayes, D.J.; Fraver, S.; Chen, G. Global pyrogenic carbon production during recent decades has created the potential for a large, long-term sink of atmospheric $\mathrm{CO}_{2}$. J. Geophys. Res. Biogeosci. 2018, 123, 3682-3696. [CrossRef]

8. Marlon, J.R.; Bartlein, P.J.; Carcaillet, C.; Gavin, D.G.; Harrison, S.P.; Higuera, P.E.; Joos, F.; Power, M.J.; Prentice, I.C. Climate and human influences on global biomass burning over the past two millennia. Nat. Geosci. 2008, 1, 697-702. [CrossRef] 
9. Aragão, L.E.O.C.; Shimabukuro, Y.E.; Cardoso, M.; Anderson, L.O.; Lima, A.; Poulter, B. Frequência de queimadas durante as secas recentes, In Secas na Amazônia: Causas e Consequências; Borma, L.D.S., Nobre, C.A., Eds.; Oficina de Textos: São Paulo, Brazil, 2013; pp. 259-279.

10. Daldegan, G.A.; Carvalho Júnior, O.A.; Guimarães, R.F.; Gomes, R.A.T.; Ribeiro, F.F.; McManus, C. Spatial patterns of fire recurrence using remote sensing and GIS in the Brazilian savanna: Serra do Tombador Nature Reserve, Brazil. Remote Sens. 2014, 6, 9873-9894. [CrossRef]

11. Moritz, M.A.; Stephens, S.L. Fire and sustainability: Considerations for California's altered future climate. Clim. Chang. 2008, 87, 265-271. [CrossRef]

12. Morello, T.F.; Parry, L.; Markusson, N.; Barlow, J. Policy instruments to control Amazon fires: A simulation approach. Ecol. Econ. 2017, 138, 199-222. [CrossRef]

13. Börner, J.; Kis-Katos, K.; Hargrave, J.; König, K. Post-crackdown effectiveness of field-based forest law enforcement in the Brazilian Amazon. PLoS ONE 2015, 10, e0121544. [CrossRef]

14. Cammelli, F.; Angelsen, A. Amazonian farmers' response to fire policies and climate change. Ecol. Econ. 2019, 165, 106359. [CrossRef]

15. Brasil. Lei no. 12.651, de 25 de Maio de 2012. Available online: http://www.planalto.gov.br/ccivil_03/_ato2011-2014/2012/lei/ 112651.htm (accessed on 18 November 2020).

16. Mistry, J.; Bilbao, B.A.; Berardi, A. Community owned solutions for fire management in tropical ecosystems: Case studies from indigenous communities of South America. Philos. Trans. R. Soc. B Biol. Sci. 2016, 371, 20150174. [CrossRef]

17. Leon, J.; Morelli, F.; Rosa, W.; Oliveira, L.; Prado, H.; Martins, G. Avanços tecnológicos na disseminação de dados ambientais e de sensoriamento remoto para a prevenção e combate aos incêndios florestais: Sistemas de dados abertos do Programa Queimadas. Biodivers. Bras. 2019, 1, 231.

18. Steil, L.; Oliveira, L.; Machado, R.; Oliveira, M.S.; Miranda, A.F. Prevention, control and monitoring of fires in the Brazilian Cerrado. Biodivers. Bras. 2020, 10, 107. [CrossRef]

19. Stott, P. Combustion in tropical biomass fires: A critical review. Prog. Phys. Geogr. Earth Environ. 2000, 24, 355-377. [CrossRef]

20. Andrade, A.S.; Daldegan, R.A.; Laranja, R.E.P.; Franca, R.R. Resultados preliminares do manejo integrado do fogo nas terras indígenas Paresi. J. Biotechnol. Biodivers. 2019, 7, 469-480. [CrossRef]

21. IBAMA. Sobre as Brigadas Federais. 2017. Available online: http://ibama.ibama.gov.br/incendios-florestais/brigadas-federais/ sobre-as-brigadas-federais (accessed on 15 December 2020).

22. Ministério da Saúde. Plano Setorial da Saúde para Mitigação e Adaptação à Mudança do Clima; Ministério da Saúde: Brasília, Brazil, 2013; p. 33.

23. IBAMA. Programa Brigadas Federais; IBAMA: Brasília, Brazil, 2012; p. 48.

24. National Interagency Fire Center. Suppression Costs. Federal Firefighting Costs (Suppression Only). 2021. Available online: https: / / www.nifc.gov / fire-information/statistics/suppression-costs (accessed on 10 September 2021).

25. New South Wales Rural Fire Service. Annual Report 2019/20. Available online: https://www.rfs.nsw.gov.au/_data/assets/ pdf_file/0008/186236/NSW-RFS-Annual-Report-2019-20.pdf (accessed on 10 September 2021).

26. Penney, G.; Habibi, D.; Cattani, M. RUIM-A fire safety engineering model for rural urban interface firefighter taskforce deployment. Fire Saf. J. 2020, 113, 102986. [CrossRef]

27. Hunter, A.L.; Shah, A.S.V.; Langrish, J.P.; Raftis, J.B.; Lucking, A.J.; Brittan, M.; Venkatasubramanian, S.; Stables, C.L.; Stelzle, D.; Marshall, J.; et al. Fire simulation and cardiovascular health in firefighters. Circulation 2017, 135, 1284-1295. [CrossRef] [PubMed]

28. Fraess-Phillips, A.; Wagner, S.; Harris, R.L. Firefighters and traumatic stress: A review. Int. J. Emerg. Serv. 2017, 6, 67-80. [CrossRef]

29. Oliveira, A.S.; Soares-Filho, B.S.; Oliveira, U.; van der Hoff, R.; Carvalho-Ribeiro, S.M.; Oliveira, A.R.; Cheepers, L.C.; Vargas, B.A.; Rajão, R.G. Costs and effectiveness of public and private fire management programs in the Brazilian Amazon and Cerrado. Forest Policy Econ. 2021, 127, 102447. [CrossRef]

30. Mistry, J.; Schmidt, I.B.; Eloy, L.; Bilbao, B. New perspectives in fire management in South American savannas: The importance of intercultural governance. Ambio 2019, 48, 172-179. [CrossRef] [PubMed]

31. Fidelis, A.; Alvarado, S.; Barradas, A.C.S.; Pivello, V.R. The year 2017: Megafires and management in the Cerrado. Fire 2018, 1, 49. [CrossRef]

32. Valente, C.R.; Latrubesse, E.M.; Ferreira, L.G. Relationships among vegetation, geomorphology and hydrology in the Bananal Island tropical wetlands, Araguaia River basin, Central Brazil. J. S. Am. Earth Sci. 2013, 46, 150-160. [CrossRef]

33. Gusmão, A.C.V.L.; Silva, B.B.; Montenegro, S.M.G.L.; Galvíncio, J.D. Determination of the net radiation in Bananal island, TO with orbital images. Rev. Bras. Eng. Agric. Ambient. 2012, 16, 1107-1114. [CrossRef]

34. Mendes, L.A.S.; Pires, E.F.; Meneses, M.E.N.S.; Behling, H. Vegetational changes during the last millennium inferred from a palynological record from the Bananal Island, Tocantins, Brazil. Acta Amaz. 2015, 45, 215-230. [CrossRef]

35. Falck, A.S.; Maggioni, V.; Tomasella, J.; Vila, D.A.; Diniz, F.L.R. Propagation of satellite precipitation uncertainties through a distributed hydrologic model: A case study in the Tocantins-Araguaia basin in Brazil. J. Hydrol. 2015, 527, 943-957. [CrossRef]

36. Ramsar. Ilha do Bananal. 2002. Available online: https://rsis.ramsar.org/ris/624 (accessed on 17 August 2020).

37. Pivello, V.R.; Coutinho, L.M. Transfer of macro-nutrients to the atmosphere during experimental burnings in an open Cerrado (Brazilian savanna). J. Trop. Ecol. 1992, 8, 487-497. [CrossRef] 
38. Abi-Eçab, P.C. Principais ameaças ao meio ambiente em terras indígenas. Planeta Amazônia 2011, 3, 1-17.

39. EarthData. MCD14ML. Available online: https://earthdata.nasa.gov/earth-observation-data/near-real-time/firms/mcd14ml (accessed on 1 September 2020).

40. Giglio, L.; Boschetti, L.; Roy, D.P.; Humber, M.L.; Justice, C.O. The Collection 6 MODIS burned area mapping algorithm and product. Remote Sens. Environ. 2018, 217, 72-85. [CrossRef]

41. Pinheiro, F.R.; Giongo, M. Qualificação e delimitação de áreas queimadas através do processamento digital de imagens TM/Landsat. Rev. Desafios 2018, 5, 30-34. [CrossRef]

42. MapBiomas. Visão Geral da Metodologia. Available online: https://mapbiomas.org/visao-geral-da-metodologia (accessed on 13 August 2019).

43. Liu, Z.; Ostrenga, D.; Teng, W.; Kempler, S. Tropical rainfall measuring mission (TRMM) precipitation data and services for research and applications. Bull. Am. Meteorol. Soc. 2012, 93, 1317-1325. [CrossRef]

44. Pereira, G.; Silva, M.; Moraes, E.; Cardozo, F. Avaliação dos dados de precipitação estimados pelo satélite TRMM para o Brasil. Rev. Bras. Recur. Hídricos 2013, 18, 139-148. [CrossRef]

45. Morelli, F.; Willian, R.; Oliveira, L.; Garrot, I. Plataforma de apoio a gestão de operações de combate a incêndios florestais: CIMAN Virtual. Biodivers. Bras. 2019, 15, 230.

46. IBAMA. Edital do Processo Seletivo Simplificado para Provimento de Vagas de Brigadista, Chefe de Esquadrão e Chefe de Brigada para Atuação em Prevenção e Combate aos Incêndios Florestais, com Lotação em Formoso do Araguaia-TO. 2020. Available online: https://www.gov.br/ibama/pt-br/acesso-a-informacao/editais-e-convites/arquivos/to/2020-06-22-ibamaprevfogo-to-editalbrifsuldailha.pdf (accessed on 3 January 2021).

47. Falleiro, R.M.; Santana, M.T.; Berni, C.R. As contribuições do manejo integrado do fogo para o controle dos incêndios florestais nas terras indígenas do Brasil. Biodivers. Bras. 2016, 6, 88-105. [CrossRef]

48. Calçavara, L.B. Ilha do Bananal em chamas: Os Karajá e o manejo do fogo em seu território. Biodivers. Bras. $2019,1,42$.

49. Marengo, J.A.; Tomasella, J.; Alves, L.M.; Soares, W.R.; Rodriguez, D.A. The drought of 2010 in the context of historical droughts in the Amazon region. Geophys. Res. Lett. 2011, 38, 1-5. [CrossRef]

50. Panisset, J.S.; Libonati, R.; Gouveia, C.M.P.; Machado-Silva, F.; França, D.A.; França, J.R.A.; Peres, L.F. Contrasting patterns of the extreme drought episodes of 2005, 2010 and 2015 in the Amazon Basin. Int. J. Climatol. 2018, 38, 1096-1104. [CrossRef]

51. Ribeiro, I.O.; Andreoli, R.V.; Kayano, M.T.; Sousa, T.R.; Medeiros, A.S.; Godoi, R.H.M.; Godoi, A.F.L.; Duvoisin, S.; Martin, S.T.; Souza, R.A.F. Biomass burning and carbon monoxide patterns in Brazil during the extreme drought years of 2005, 2010, and 2015. Environ. Pollut. 2018, 243, 1008-1014. [CrossRef]

52. Alvarado, S.T.; Fornazari, T.; Cóstola, A.; Morellato, L.P.C.; Silva, T.S.F. Drivers of fire occurrence in a mountainous Brazilian Cerrado savanna: Tracking long-term fire regimes using remote sensing. Ecol. Indic. 2017, 78, 270-281. [CrossRef]

53. Mistry, J. Fire in the cerrado (savannas) of Brazil: An ecological review. Prog. Phys. Geogr. 1998, 22, 425-448. [CrossRef]

54. Govender, N.; Trollope, W.S.W.; van Wilgen, B.W. The effect of fire season, fire frequency, rainfall and management on fire intensity in savanna vegetation in South Africa. J. Appl. Ecol. 2006, 43, 748-758. [CrossRef]

55. Miranda, A.C.; Miranda, H.S.; Dias, I.D.F.O.; Souza Dias, B.F. Soil and air temperatures during prescribed cerated fires in Central Brazil. J. Appl. Ecol. 1993, 9, 313-320. [CrossRef]

56. Miranda, H.S.; Sato, M.N.; Nascimento Neto, W.; Aires, F.S. Fires in the Cerrado, the Brazilian savanna. Trop. Fire Ecol. 2009, 2 , 427-450. [CrossRef]

57. Gomes, L.; Miranda, H.S.; Bustamante, M.M.C. How can we advance the knowledge on the behavior and effects of fire in the Cerrado biome? For. Ecol. Manag. 2018, 417, 281-290. [CrossRef]

58. Mataveli, G.A.V.; Silva, M.E.S.; Pereira, G.; Cardozo, F.S.; Kawakubo, F.S.; Bertani, G.; Costa, J.C.; Ramos, R.C.; Silva, V.V. Satellite observations for describing fire patterns and climate-related fire drivers in the Brazilian savannas. Nat. Hazards Earth Syst. Sci. 2018, 18, 125-144. [CrossRef]

59. Schmidt, I.B.; Fonseca, C.B.; Ferreira, M.C.; Sato, M.N. Experiências internacionais de manejo integrado do fogo em áreas protegidas-Recomendações para implementação de manejo integrado de fogo no Cerrado. Biodivers. Bras. 2016, 6, 41-54. [CrossRef]

60. Franke, J.; Barradas, A.C.S.; Borges, M.A.; Costa, M.M.; Dias, P.A.; Hoffmann, A.A.; Orozco Filho, J.C.; Melchiori, A.E.; Siegert, F. Fuel load mapping in the Brazilian Cerrado in support of integrated fire management. Remote Sens. Environ. 2018, 217, 221-232. [CrossRef]

61. Coutinho, L.M. Fire in the ecology of the Brazilian Cerrado. In Fire in the Tropical Biota; Goldammer, J.G., Ed.; Springer: Berlin/Heidelberg, Germany, 1990; pp. 82-105.

62. Pivello, V.R. The use of fire in the Cerrado and Amazonian rainforests of Brazil: Past and present. Fire Ecol. 2011, 7, 24-39. [CrossRef]

63. Medeiros, M.B.; Miranda, H.S. Mortalidade pós-fogo em espécies lenhosas de campo sujo submetido a três queimadas prescritas anuais. Acta Bot. Brasilica 2005, 19, 493-500. [CrossRef]

64. Coutinho, L.M. Ecological effects of fire in Brazilian Cerrado. In Ecology of Tropical Savannas; Huntley, B.J., Walker, B.H., Eds.; Springer: Berlin/Heidelberg, Germany, 1982; pp. 273-291.

65. Miranda, H.S.; Sato, M.N. Efeitos do fogo na vegetação lenhosa do Cerrado. In Cerrado: Ecologia, Biodiversidade e Conservação; Scariot, A., Sousa-Silva, J.C., Felfili, J.M., Eds.; Ministério do Meio Ambiente: Brasília, Brazil, 2005. 
66. Armando, M.S. O Impacto do Fogo na Rebrota de Algumas Espécies de Árvores do Cerrado. Master's Thesis, Universidade de Brasília, Brasília, Brazil, 1994.

67. Aguiar, L.L.L.; Martins, P.T.A. Fire regime in the Pimentel Barbosa Indigenous Land, Mato Grosso, Brazil. Mercator 2020, 19 , 1-21. [CrossRef]

68. Gomes, L.; Miranda, H.S.; Soares-Filho, B.; Rodrigues, L.; Oliveira, U.; Bustamante, M.M.C. Responses of plant biomass in the Brazilian savanna to frequent fires. Front. For. Glob. Chang. 2020, 3, 116. [CrossRef]

69. Schmidt, I.B.; Moura, L.C.; Ferreira, M.C.; Eloy, L.; Sampaio, A.B.; Dias, P.A.; Berlinck, C.N. Fire management in the Brazilian savanna: First steps and the way forward. J. Appl. Ecol. 2018, 55, 2094-2101. [CrossRef]

70. Hoffmann, W.A.; Geiger, E.L.; Gotsch, S.G.; Rossatto, D.R.; Silva, L.C.R.; Lau, O.L.; Haridasan, M.; Franco, A.C. Ecological thresholds at the savanna-forest boundary: How plant traits, resources and fire govern the distribution of tropical biomes. Ecol. Lett. 2012, 15, 759-768. [CrossRef] [PubMed]

71. Fidelis, A.; Pivello, V. Deve-se usar o fogo como instrumento de manejo no Cerrado e Campos Sulinos? Biodivers. Bras. 2011, 2, 12-25. [CrossRef]

72. Durigan, G. Zero-fire: Not possible nor desirable in the Cerrado of Brazil. Flora 2020, 268, 151612. [CrossRef]

73. Santos, F.L.M.; Nogueira, J.; Souza, R.A.F.; Falleiro, R.M.; Schmidt, I.B.; Libonati, R. Prescribed burning reduces large, highintensity wildfires and emissions in the Brazilian savanna. Fire 2021, 4, 56. [CrossRef] 